\section{Comparative Performance of Reduced-risk Fungicides and Biorational Products in Management of Postharvest Botrytis Blight on Bigleaf Hydrangea Cut Flowers}

\author{
Ravi Bika ${ }^{1}$, Cristi Palmer ${ }^{2}$, Lisa Alexander ${ }^{3}$, \\ and Fulya Baysal-Gurel ${ }^{1}$
}

AdDITIONAL INDEX wORDs. Botrytis cinerea, cut flowers, disease management, Hydrangea macrophylla, postharvest vase life

Summary. Botrytis cinerea is one of the problematic and notorious postharvest pathogens of bigleaf hydrangea (Hydrangea macropbylla) cut flowers. It causes flower blight, leaf blight, and stem rot, reducing the ornamental value (such as longevity, color, and texture) of flowers, ultimately making them unsalable. The objective of this study was to identify effective conventional fungicides and biorational products for botrytis blight management on bigleaf hydrangea cut flowers that can be easily and readily adopted by growers of ornamentals. Preventive preharvest whole-plant spray and postharvest dip treatment applications were used in this study. For the whole-plant spray applications, bigleaf hydrangea plants were sprayed with treatment solution 3 days before harvesting flowers. For the dip applications, cut flowers were dipped in treatment solutions after harvest. For both application types, flowers were inoculated with $B$. cinerea spores once treatment solutions dried. Flowers were stored in cold storage for 3 days and then displayed in conditions similar to retail stores. Botrytis blight disease severity, marketability of flower (postharvest vase life), phytotoxicity, and application residue were assessed in the study. Treatments showed variable efficacy in managing postharvest $B$. cinerea infection in bigleaf hydrangea cut flowers. Preventive preharvest whole-plant spray and postharvest dip applications of isofetamid and fluxapyroxad + pyraclostrobin significantly reduced the postharvest botrytis blight disease severity and area under disease progress curve (AUDPC) compared with the positive control (nontreated, inoculated with $B$. cinerea). When applied as a postharvest dip, the fungicide fludioxonil and biofungicide Aureobasidium pullulans strains DSM 14940 and DSM 14941 effectively lowered the disease severity and disease progress (AUDPC). These effective treatments also maintained a significantly longer postharvest vase life of bigleaf hydrangea cut flowers compared with the nontreated, inoculated control. The longer vase life may be attributed to lowered botrytis blight disease severity and the resultant proper physiological functioning of flowers.

$\mathrm{H}$ ydrangeas (Hydrangea sp.) are popular deciduous flowering shrubs that are widely used as cut flowers, potted plants, and landscape plants (Adkins et al., 2003; Arafa et al., 2017; Kazaz et al., 2020; Pagter and Williams, 2011). Hydrangeas are the second top-selling ornamental shrub in the United States and are produced in more than 1500 nurseries nationwide (Fulcher et al., 2016). The market for hydrangea cut flowers is increasing, with hydrangea sales growing 64\% between 2007 and 2014 to over $\$ 120$ million per year (U.S. Department of Agriculture, 2014). The most popular species of hydrangea in the cut flower market is bigleaf hydrangea (Hydrangea macrophylla) because of its attractive flower and variable sepal color (Kazaz et al.,
2020). The sepal color of bigleaf hydrangea ranges from white to red, pink, blue, or purple with a diversity of hues (light to dark) depending upon the cultivar, soil $\mathrm{pH}$, and availability of aluminum (McClintock, 1957; Yoshida et al., 2003).

The floriculture market depends upon the ornamental characteristics of flowers such as longevity, shape, size, color, form, and texture (Seglie et al., 2009). However, bigleaf hydrangea flowers are greatly affected by the plant pathogenic fungus Botrytis cinerea (Baysal-Gurel et al., 2016). Botrytis blight disease reduces the ornamental quality of cut flowers, which makes them unsalable and represents a huge economic burden to growers. This opportunistic fungus has a devastating impact in both greenhouse and field production, and in postharvest environments, including storage and transportation. The fungal pathogen $B$. cinerea causes petal specking, leaf and fruit rots, and flower blight on many important horticultural crops, including ornamentals (Bika et al., 2020; Darras et al., 2005; Salinas and Verhoeff, 1995; Tomas et al., 1995). Infection with the pathogen usually starts in the early growth and development of a plant under certain environmental conditions, but the pathogen may remain quiescent and inactive (Prusky, 1996), becoming aggressive when it senses certain physical and physiological changes in the host's tissue (Williamson et al., 2007). Disease symptoms due to latent infections are often expressed in postharvest conditions (Muñoz et al., 2019).

Routine fungicide application (multisite and/or site-specific) has been the primary tool for the management of botrytis blight in greenhouse and field production. There are numerous multisite fungicides such as captan [Fungicide Resistance Action Committee code (FRAC) M3] and thiram (FRAC M4), and site-specific fungicides such as anilinopyrimidines (FRAC 9), quinone outside inhibitors [QoI (FRAC 11)], succinate dehydrogenase inhibitors [SDHI (FRAC 7)], phenylpyrroles (FRAC 12), and sterol biosynthesis inhibitors class III (FRAC 17) that are available in the market (Fernández-Ortuño et al., 2015). In the past, benzimidazoles (FRAC 1) and dicarboximides (FRAC

\begin{tabular}{llll}
\hline $\begin{array}{l}\text { Units } \\
\text { To convert U.S. to SI, } \\
\text { multiply by }\end{array}$ & U.S. unit & SI unit & $\begin{array}{l}\text { To convert SI to U.S., } \\
\text { multiply by }\end{array}$ \\
\hline 29.5735 & $\mathrm{fl} \mathrm{oz}$ & $\mathrm{mL}$ & 0.0338 \\
7.8125 & $\mathrm{fl} \mathrm{oz} / \mathrm{gal}$ & $\mathrm{mL} \cdot \mathrm{L}^{-1}$ & 0.1280 \\
3.7854 & $\mathrm{gal}$ & $\mathrm{L}$ & 0.2642 \\
0.5933 & $\mathrm{lb} / \mathrm{yard}{ }^{3}$ & $\mathrm{~kg} \cdot \mathrm{m}^{-3}$ & 1.6856 \\
7.4892 & $\mathrm{Oz} / \mathrm{gal}^{\circ}$ & $\mathrm{g} \cdot \mathrm{L}^{-1}$ & 0.1335 \\
$\left({ }^{\circ} \mathrm{F}-32\right) \div 1.8$ & ${ }^{\circ} \mathrm{F}$ & ${ }^{\circ} \mathrm{C}$ & $\left({ }^{\circ} \mathrm{C} \times 1.8\right)+32$
\end{tabular}


2) were used for the management of $B$. cinerea. However, the efficacy of these fungicides was limited (Elad, 1988), and they are no longer recommended for botrytis blight management (Sun et al., 2010). In the mid-1990s, different new group compounds such as anilinopyrimidines (cyprodinil), phenylpyrrole (fludioxonil), and hydroxyanilide (fenhexamid) were introduced (Rosslenbroich and Stuebler, 2000). The anilinopyrimidines do not affect the germination of spores but do prevent the growth of germ tube and mycelium of the fungus. In addition, they also inhibit the secretion of cell wall degrading enzymes by $B$. cinerea (Milling and Richardson, 1995). Similarly, phenylpyrrole and hydroxyanilide materials inhibit spore germination and induce swelling, bursting, and debranching of mycelium and germ tubes (Debieu et al., 2001; Leroux, 1996). Recently, SDHI fungicides such as boscalid, isofetamid, and fluxapyroxad have been introduced that effectively manage botrytis blight in various crops, including woody ornamentals (BaysalGurel and Simmons, 2017; Sierotzki and Scalliet, 2013). This fungicide class inhibits $B$. cinerea growth and development by blocking cellular or

Received for publication 24 May 2020. Accepted for publication 2 Sept. 2020.

Published online 5 October 2020.

${ }^{1}$ Tennessee State University, Otis L. Floyd Research Center, Department of Agriculture and Environmental Sciences, McMinnville, TN 37110

${ }^{2}$ Rutgers University, IR-4, 500 College Road East, Suite 201, Princeton, NJ 08540

${ }^{3}$ U.S. Department of Agriculture, Agricultural Research Service, U.S. National Arboretum, Floral and Nursery Plants Research Unit, Otis L. Floyd Nursery Research Center, 472 Cadillac Lane, McMinnville, TN 37110

This project was funded by the IR- 4 Project (USDA-NIFA award number 2017-34383-27100)

We thank BASF, Bayer, BioSafe, BioWorks, OHP, Marrone Bio Innovations, Syngenta, and Westbridge Agriculture Products for donating the conventional fungicides and biorational products used in this study. We thank Terri Simmons for her help with setting up the experiment.

Mention of trade names of commercial products in the publication is solely for the purpose of providing specific information and does not imply recommendation or endorsement by the U.S. Department of Agriculture, IR-4 Project, or Tennessee State University.

F.B.-G. is the corresponding author. E-mail: fbaysalg@tnstate.edu.

This is an open access article distributed under the CC BY-NC-ND license (https://creativecommons.org/ licenses/by-nc-nd/4.0/).

https://doi.org/10.21273/HORTTECH04656-20 mitochondrial respiration (Piqueras et al., 2014).

The invention and development of fungicides with new chemical compounds have played crucial roles in maintaining value and stability of production. However, the number of fungicides registered for environmental horticulture crops has been decreasing due to disease resistance development, as well as environmental and human health issues (Gullino and Garibaldi, 2007). B. cinerea resistance to single-site fungicides such as thiophanate-methyl (FRAC 1), iprodione (FRAC 2), boscalid (FRAC 7), cyprodinil (FRAC 9), fludioxonil (FRAC 12), and fenhexamid (FRAC 17) has been observed worldwide across greenhouse, storage, and shipment conditions (Muñoz et al., 2019; Rodríguez et al., 2014; Rupp et al., 2017). Therefore, new a.i. with different modes of action that are socioenvironmentally friendly need to be sought.

The resistance of pathogens to fungicides has increased the interest in development and adoption of biorational products for fungal disease management (Fravel, 2005). "Biorational" refers to pesticides (botanicals, minerals, microorganisms, and minimum-risk chemicals) of natural origin that have low or no negative effect on beneficial organisms and the environment (Reddy, 2016). Numerous studies have shown that use of beneficial fungi, such as Clonostachys rosea (synonym Gliocladium roseum), Ulocladium atrum, and the Trichoderma species, has effectively provided botrytis blight management in cyclamen (Cyclamen persicum), geranium (Pelargonium sp.), rose (Rosa sp.), moth orchid (Phalaenopsis sp.), and begonia (Begonia sp.) (Morandi et al., 2000; Sutton et al., 1997; Zaldúa and Sanfuentes, 2010; Zhao et al., 2018). Similarly, some of the yeasts such as black yeast (Exophiala jeanselmei), and bacteria such as $B a$ cillus subtilis substantially suppress $B$. cinerea in rose flowers (Redmond, 1987; Tatagiba et al., 1998). Botanical products [e.g., giant knotweed (Reynoutria sachalinensis) extract] and mineral salts (e.g., mono and dibasic salt of phosphorous) also have been used for botrytis blight management in various crops (Reddy, 2016). However, biorational products were limited in their efficacy when applied to wider field conditions ( $\mathrm{Hu}$ et al., 2009). In addition, they typically cannot provide enough protection from $B$. cinerea infection when the inoculum loads are high, but they can be useful for rotation or combination with fungicides for improved management of preharvest and postharvest $B$. cinerea infection.

An integrated management program including good sanitation practices, greenhouse environmental control, fungicides, and biorational products is required for the successful management of botrytis blight and for U.S. ornamental growers to remain competitive in the floriculture market. The objective of this study was to evaluate different fungicides and biorational products for the management of postharvest $B$. cinerea infection and postharvest vase life of bigleaf hydrangea cut flowers. The fungicides and biorational products were also assessed for phytotoxicity and application residue on cut flowers. The results of this study will provide growers of ornamentals with potential treatments for botrytis blight management.

\section{Materials and methods}

Plant material. 'Nikko Blue' bigleaf hydrangea plants were purchased from commercial nurseries in 2017 and maintained in 5-gal pots in a greenhouse for 2 years at the Tennessee State University Otis L. Floyd Nursery Research Center (TSUNRC), McMinnville, TN. Growing media consisted of $100 \%$ pine bark amended with $11.12 \mathrm{lb} /$ yard $^{3} 19 \mathrm{~N}-2.1 \mathrm{P}-7.4 \mathrm{~K}$ controlled-release fertilizer (Osmocote Pro; ICL Specialty Fertilizers, Dublin, OH), $1.01 \mathrm{lb} /$ yard $^{3}$ micronutrient fertilizer (Micromax, ICL Specialty Fertilizers), $1.01 \mathrm{lb} /$ yard $^{3}$ iron sulfate, and $0.34 \mathrm{lb} /$ yard $^{3}$ Epsom salts. Irrigation was applied using micro bubbler emitters installed on short stakes in a greenhouse and maintained for 2, 3, and 4 min twice per day with the amount of $0.5,0.75$, and $1 \mathrm{~L}$ of water per day in May, June, and July, respectively. The bigleaf hydrangea plants did not receive any pesticides other than test products. 'Nikko Blue' bigleaf hydrangea has panicle-type inflorescences that contain small, fertile flowers and large, showy sepals. The term "flower" used in this article 
refers to a single harvested stem with its panicle of flowers and sepals. The bigleaf hydrangea flowers were harvested when sepals began showing color. Average temperatures in the greenhouse for May, June, and July were $23.5^{\circ} \mathrm{C}\left[27.4 / 17.6^{\circ} \mathrm{C}\right.$ (maximum/minimum) ], $23.9{ }^{\circ} \mathrm{C}(27.3 /$ $18.1{ }^{\circ} \mathrm{C}$ ), and $24.1{ }^{\circ} \mathrm{C}$ (28.7/ $19.2^{\circ} \mathrm{C}$ ), respectively; average relative humidity (RH) was $94.5 \%$, $95.7 \%$, and $95.5 \%$, respectively.

FUNGAL INOCULUM PREPARATION. Isolate FBG2015-02 of B. cinerea was obtained from the culture collection of F. Baysal-Gurel at TSUNRC. The $B$. cinerea specimen was originally isolated from a diseased 'Nikko Blue' bigleaf hydrangea and maintained on potato dextrose agar (PDA) medium (Sigma-Aldrich, St. Louis, MO). Before this study, 'Nikko Blue' bigleaf hydrangea flowers and leaves were inoculated with a $B$. cinerea conidial suspension, and the pathogen was subsequently re-isolated from the diseased flowers and leaves to ensure virulence. For the preparation of inoculum, $B$. cinerea cultures were grown on PDA medium at $21^{\circ} \mathrm{C}$ with $24 \mathrm{~h}$ fluorescent light. The conidial suspension was prepared by flooding a 10- to 14-d-old culture of $B$. cinerea with sterile distilled water, filtering it through cheesecloth, and then diluting it with sterile distilled water containing $0.1 \%(\mathrm{w} / \mathrm{v})$ nonionic surfactant [polyoxyethylenesorbitan monolaurate (Tween 20; SigmaAldrich, St. Louis, MO)]. Conidial concentration was determined using a hemocytometer (Hausser Scientific, Horsahm, PA) under a light microscope (BX50; Olympus, Center Valley, PA). The final concentration was adjusted to $1 \times 10^{6}$ conidia $/ \mathrm{mL}$ using $C_{1} V_{1}=C_{2} V_{2}$, where $C_{1}$ is concentration of spores from hemocytometer count, $V_{1}$ is volume of suspension needed, $C_{2}$ is desired concentration of spores, and $V_{2}$ is the final desired volume of suspension.

TreatMents AND EXPERIMENTAL DESIGN. The study was conducted at the TSUNRC, and 2-year-old 'Nikko blue' bigleaf hydrangea plants were used for the experiment. Five fungicides and five biorational products were evaluated for their ability to manage botrytis blight on bigleaf hydrangea cut flowers following the IR-4 Environmental Horticulture Program protocol 19-002 (IR-4
Project, 2019) (Table 1). Treatments were applied according to the recommended rates provided by registrants. Control treatments included nontreated, inoculated (positive control) and nontreated, noninoculated (negative control). Two treatment methods were used for this study: Preharvest whole-plant spray and postharvest dip applications. The rates of the treatments were the same for whole-plant spray and dip applications (Table 1). Even though fluxapyroxad + pyraclostrobin (Orkestra Intrinsic; BASF, Florham Park, NJ) and fluopyram + trifloxystrobin (Broadform; Bayer, Whippany, NJ) were recommended only for preharvest whole-plant spray application according to IR-4 protocol, they also were included in the dip application study to learn whether this method of application would be safe to the bigleaf hydrangea cut flowers and effective against botrytis blight. Multiple harvestings of flowers from the same set of bigleaf hydrangea plants were used for both experiments.

Whole-plant spray applications of fungicides or biorational products were applied as preventive preharvest treatments on bigleaf hydrangea plants (including foliage and flowers). The trial was carried out from 15-31 July 2019. Five single plant replications per treatment were arranged in a completely randomized design. Plants were sprayed with treatments until runoff, using a backpack carbon dioxide $\left(\mathrm{CO}_{2}\right)$-pressurized sprayer (Bellspray, Opelousas, LA) with a tapered-edge flat-spray pattern stainless-steel nozzle (TP8002VS; TeeJet Technologies, Springfield, IL) at 40 psi, $3 \mathrm{~d}$ before harvesting flowers. The plants were left for about $3 \mathrm{~h}$ for drying of the applied treatment solution. Then the whole plant, including flowers and foliage, was artificially inoculated by uniformly spraying foliage and flowers with a $B$. cinerea spore suspension $\left(10^{6}\right.$ conidia $\left./ \mathrm{mL}\right)$ using a hand-held sprayer. The negative control plants were sprayed with only the sterile distilled water containing $0.1 \%(\mathrm{w} / \mathrm{v})$ of nonionic surfactant (Tween 20). The bigleaf hydrangea plants were left in the greenhouse for $3 \mathrm{~d}$, and then five single-flower replications per treatment were harvested.

Dip applications of conventional fungicides and biorational products were done as preventive postharvest treatments against botrytis blight. The first trial of dip application was conducted from 13-24 May 2019, and the second trial was conducted from 15-30 June 2019. Each treatment had six single-flower replications, which were arranged in a completely randomized design. The freshly harvested bigleaf hydrangea flowers were dipped for $10 \mathrm{~s}$ in prepared solutions of treatments according to protocol rates. The flowers were left for about $2 \mathrm{~h}$ for drying of the treatments, then they were artificially inoculated by uniformly spraying with the $B$. cinerea spore suspension $\left(10^{6}\right.$ conidia $\left./ \mathrm{mL}\right)$ using a hand-held sprayer. The negative control flowers were sprayed with only sterile distilled water containing $0.1 \%(\mathrm{w} / \mathrm{v})$ nonionic surfactant (Tween 20), while positive control flowers were sprayed with the $B$. cinerea spore suspension.

The cut flowers were maintained in $900-\mathrm{mL}$ beakers filled with tap water and placed in cold storage for $3 \mathrm{~d}$ at $4{ }^{\circ} \mathrm{C}$, using a completely randomized design. Flowers were then displayed in normal room conditions, using a completely randomized design. The average maximum and minimum temperatures and $\mathrm{RH}$ were monitored using a weather station (WatchDog 2700; Spectrum Technologies, Aurora, IL). The average minimum and maximum temperatures of room condition for preharvest whole-plant spray (21-31 July 2019), postharvest dip Trial I (1624 May 2019), and postharvest dip Trial II (18-30 June 2019) were 19 and $23{ }^{\circ} \mathrm{C}, 18$ and $24{ }^{\circ} \mathrm{C}$, and 18.5 and $23{ }^{\circ} \mathrm{C}$, respectively; and average RH was $66 \%, 68 \%$, and $62 \%$, respectively.

Data recording. Evaluations were made on botrytis blight disease severity and phytotoxicity using a 1 to 5 ordinal scale $[1=$ no symptom $(0 \%)$, $2=1 \%$ to $25 \%$ sepals affected, $3=26 \%$ to $50 \%$ sepals affected, $4=51 \%$ to $75 \%$ sepals affected, $5=76 \%$ to $100 \%$ sepals affected], and marketability of cut flowers using a 1 to 5 ordinal scale $(1=$ dead, $2=$ poor quality, $3=$ commercially acceptable, $4=$ good quality, $5=$ healthy). Evaluations were done every $2 \mathrm{~d}$ until the negative control flowers began to degrade in appearance. The ordinal scale values were converted into percentages using the midpoint value as described 
Table 1. List of fungicides and biorational products and application rates according to IR-4 protocol for management of botrytis blight on bigleaf hydrangea cut flowers. All treatments were used for both dip application and whole-plant spray application.

\begin{tabular}{|c|c|c|c|c|}
\hline Treatment $^{\mathrm{z}}$ & $\begin{array}{l}\text { Product a.i. } \\
(\%)\end{array}$ & $\begin{array}{l}\text { Product application } \\
\text { rate }^{\mathrm{y}}\end{array}$ & $\begin{array}{l}\text { Product } \\
\text { group }^{\mathrm{x}}\end{array}$ & $\begin{array}{l}\text { FRAC } \\
\text { codew }^{\text {w }}\end{array}$ \\
\hline Aureobasidium pullulans strains DSM 14940 and DSM 14941 & $40+40$ & $0.75 \mathrm{~g} \cdot \mathrm{L}^{-1}$ & BCA & NC \\
\hline Fludioxonil & 11.8 & $0.30 \mathrm{~mL} \cdot \mathrm{L}^{-1}$ & Phenylpyrrole & 12 \\
\hline Fluopyram + trifloxystrobin & $21.4+21.4$ & $0.60 \mathrm{~mL} \cdot \mathrm{L}^{-1}$ & SDHI + QoI & $7+11$ \\
\hline Fluxapyroxad + pyraclostrobin & $21.26+21.26$ & $0.60 \mathrm{~mL} \cdot \mathrm{L}^{-1}$ & $\mathrm{SDHI}+\mathrm{QoI}$ & $7+11$ \\
\hline Giant knotweed extract & 5 & $10 \mathrm{~mL} \cdot \mathrm{L}^{-1}$ & Plant extract & P 05 \\
\hline Iprodione & 23.3 & $1.25 \mathrm{~mL} \cdot \mathrm{L}^{-1}$ & Dicarboximide & 2 \\
\hline Isofetamid & 36 & $1.05 \mathrm{~mL} \cdot \mathrm{L}^{-1}$ & SDHI & 7 \\
\hline $\begin{array}{l}\text { Mono- and di-potassium salts of phosphorus acid }+ \text { hydrogen } \\
\text { peroxide }\end{array}$ & $27.1+14$ & $10 \mathrm{~mL} \cdot \mathrm{L}^{-1}$ & Phosphonate & P 07 \\
\hline SP2480 experimental extract ${ }^{\mathrm{V}}$ & unknown & $2.34 \mathrm{~mL} \cdot \mathrm{L}^{-1}$ & & $\mathrm{NC}$ \\
\hline Ulocladium oudemansii strain $\mathrm{U}^{\mathrm{u}}$ & 45 & $3.60 \mathrm{~g} \cdot \mathrm{L}^{-1}$ & $\mathrm{BCA}$ & $\mathrm{NC}$ \\
\hline
\end{tabular}

${ }^{\mathrm{z}}$ A. pullulans strains DSM 14940 and DSM 14941 (Botector; Westbridge Agriculture Products, Vista, CA), fludioxonil (Medallion; Syngenta, Greensboro, NC), fluopyram + trifloxystrobin (Broadform; Bayer, Whippany, NJ), fluxapyroxad + pyraclostrobin (Orkestra Intrinsic; BASF, Florham Park, NJ), giant knotweed extract (Regalia; Marrone Bio Innovations, Davis, CA), iprodione (Chipco 26019, Bayer), isofetamid (Astun; OHP, Bluffton, SC), mono and di-potassium salts of phosphorus acid + hydrogen peroxide (OxiPhos; BioSafe Systems, Harford, CT), SP2480 (SePRO, Carmel, IN), U. oudemansii strain U3 (BWI65N; BioWorks, Victor, NY).

${ }^{\mathrm{y}} 1 \mathrm{~g} \cdot \mathrm{L}^{-1}=0.1335 \mathrm{oz} / \mathrm{gal}, \mathrm{l} \mathrm{mL} \cdot \mathrm{L}^{-1}=0.1280 \mathrm{fl} \mathrm{oz} / \mathrm{gal}$.

${ }^{\mathrm{x}} \mathrm{SDHI}=$ succinate dehydrogenase inhibitor, $\mathrm{QoI}=$ quinone outside inhibitor, $\mathrm{BCA}=$ biological control agent.

${ }^{\mathrm{w}}$ Fungicide Resistance Action Committee code; $\mathrm{NC}=$ not classified.

'Nonionic surfactant (CapSil; Aquatrols, Paulsboro, NJ) used with SP2480 at a rate of $0.3 \mathrm{~mL} \cdot \mathrm{L}^{-1}$

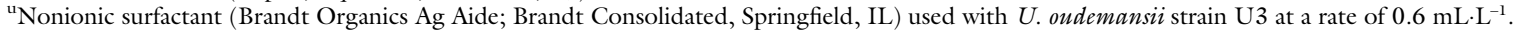

by Bock et al. (2009). The area under disease progress curve (AUDPC) was calculated using formula $\sum\left\{\left[\left(x_{\mathrm{i}}+x_{\mathrm{i}}-\right.\right.\right.$ 1) $\left./ 2]\left(t_{\mathrm{i}}-t_{\mathrm{i}}-1\right)\right\}$, where $x_{\mathrm{i}}$ is botrytis blight disease severity rating midpoint value on each evaluation date, and $\left(t_{\mathrm{i}}-t_{\mathrm{i}}-1\right)$ is the number of days between evaluations. Floral longevity (vase life) is the period (days) from harvest until flower marketability was no longer rated 3 or higher. Floral longevity was calculated using the formula $\sum\left(x_{1}+x_{2}+x_{3}+\ldots \ldots+x_{n}\right)$, where $x_{1}, x_{2}, x_{3}, \ldots x_{n}$ were the marketability ratings on each evaluation date, and $x_{1}=1$ if $x_{1} \geq 3$ on the marketability scale, otherwise $x_{1}=0$; $x_{2}=3$ if $x_{2} \geq 3$ on the marketability scale, otherwise $x_{2}=2 ; x_{3} \ldots x_{\mathrm{n}}=2$ if $x_{3} \ldots x_{\mathrm{n}} \geq 3$ on the marketability scale, otherwise $x_{3} \ldots x_{1}=0$. The absence or presence of application residue was also recorded for each treatment.

Statistical analysis. Botrytis blight disease severity, AUDPC, and floral longevity were compared among treatments for two types of application methods. SAS software (version 9.4 for Windows; SAS Institute, Cary, NC) was used to run statistical analysis of data. SigmaPlot software (version 14 for Windows; Systat Software, San Jose, CA) was used for graphical representation of data. One-way analysis of variance was performed using the general linear model procedure (PROC GLM) and Welch's $t$ test to partition variance in disease severity index, AUDPC, and longevity into sources attributable to treatment and error. Welch's $t$ test is a modification of Student's $t$ test that does not assume equal variances (Welch, 1947; Zheng et al., 2013). Treatment means were separated using Tukey's Studentized range test at the $5 \%$ level of significance.

\section{Results}

EFFICACY OF PREVENTIVE PREHARVEST WHOLE-PLANT SPRAY APPLICATION OF FUNGICIDES AND BIORATIONAL PRODUCTS. The first botrytis blight symptom on bigleaf hydrangea flower was observed on the day 4 of the trial (immediately after removing plants from $3 \mathrm{~d}$ of cold storage). The negative control flowers had the lowest botrytis blight disease severity and disease progress, whereas the positive control had the highest disease severity $(F=29.29$, $P<0.001)$ and disease progress $(F=$ $22.67, P<0.001$ ) (Table 2 ). The longest postharvest vase life $(13 \mathrm{~d})$ of bigleaf hydrangea cut flowers was observed in the negative control $(F=$ 6.82, $P<0.001$ ) (Fig. 1).

Preharvest whole-plant spray application of fluxapyroxad + pyraclostrobin $(7.8 \%)$ and isofetamid $(13 \%)$ effectively reduced postharvest botrytis blight disease severity compared with the positive control flowers (88\%) (Table 2). Fluopyram + trifloxystrobin, iprodione, and mono and di-potassium salts of phosphorus acid + hydrogen peroxide were not effective in reducing postharvest botrytis blight severity and disease progression. Preharvest whole-plant spray application of fungicides fluxapyroxad + pyraclostrobin and isofetamid significantly lowered disease progress compared with the positive control and were statistically equivalent to the negative controls. The remaining treatments (fludioxonil, SP2480, Ulocladium oudemansii strain U3, Aureobasidium pullulans strains DSM 14940 and DSM 14941, and giant knotweed extract) numerically reduced postharvest disease progress; however, they were not statistically different from the positive control flowers.

The positive control had the shortest postharvest vase life of bigleaf hydrangea cut flowers (4 d) (Fig. 1). Whole-plant spray applications of fluxapyroxad + pyraclostrobin (12 d) and isofetamid (10 d) effectively extended the postharvest vase life of cut flowers and were statistically like the negative control flowers. No other treatment was effective in extending postharvest vase life compared with the positive control flowers.

Phytotoxicity was not observed in any of the treated bigleaf hydrangea 


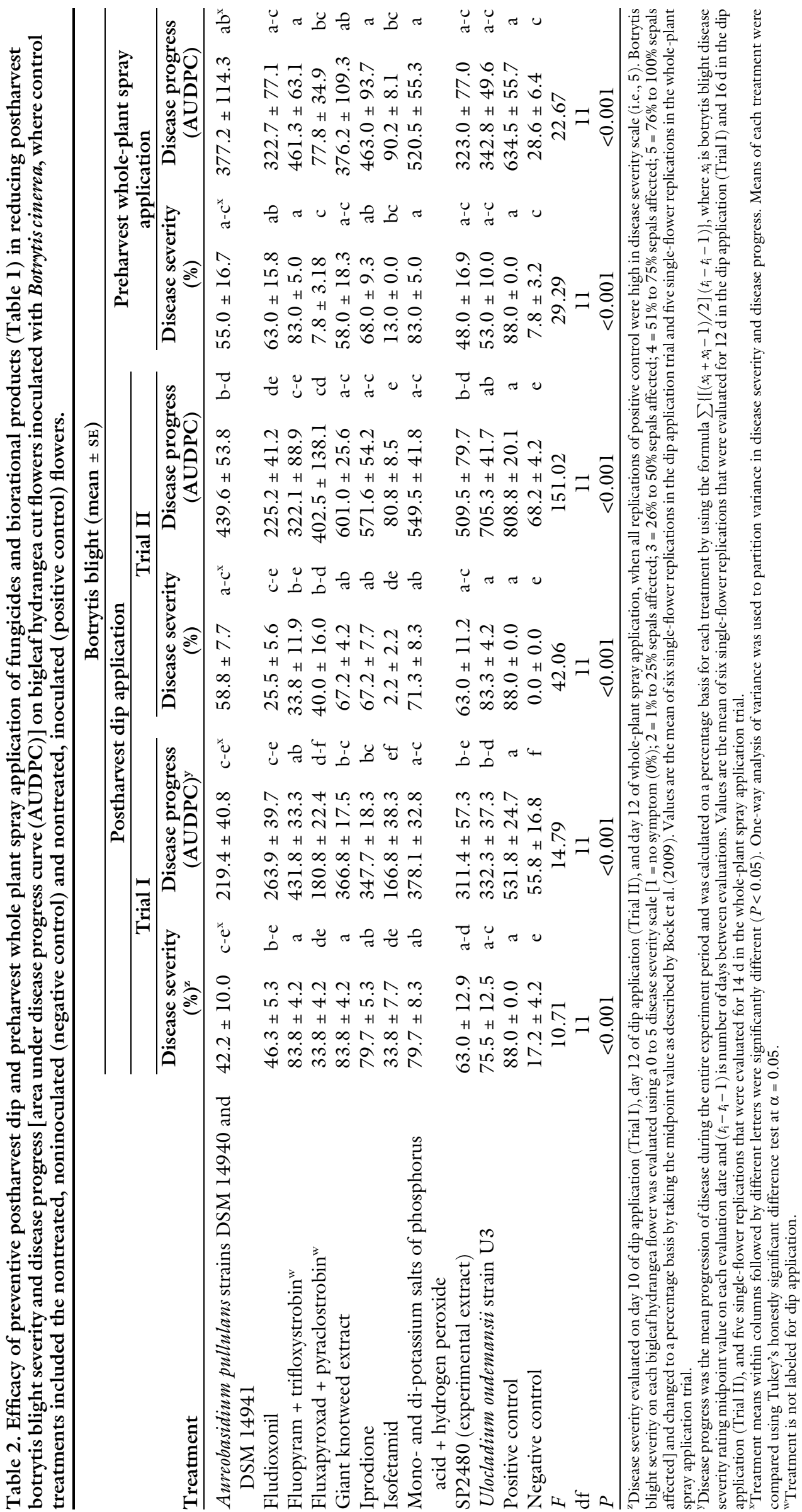




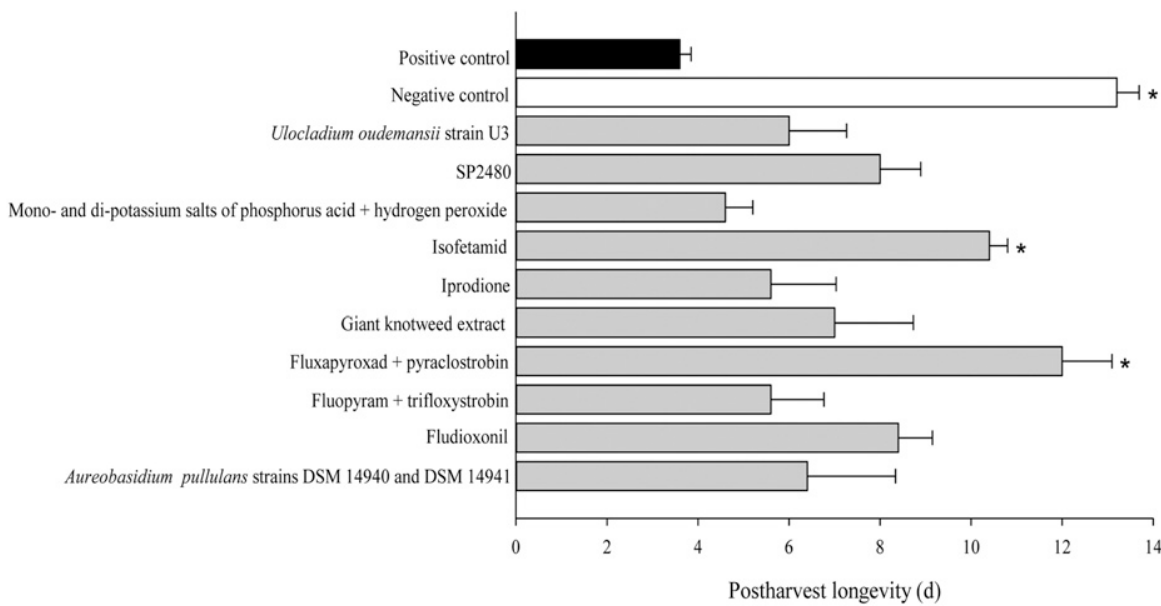

Fig. 1. Postharvest longevity (mean $\pm \mathrm{SE}$ ) of bigleaf hydrangea cut flowers after application of preharvest whole-plant spray of fungicides and biorational products (Table 1) and inoculation with Botrytis cinerea. The fungicides and biorational products were sprayed until runoff $3 \mathrm{~d}$ before the harvesting of the bigleaf hydrangea flowers. Longevity is the period from harvest until flowers were rated 3 or more in marketability scale. Marketability of cut flowers was evaluated using a 1 to 5 ordinal scale $(1=$ dead, $2=$ poor quality, $3=$ commercially acceptable, $4=$ good quality, 5 = healthy). Control treatments included the nontreated, noninoculated (negative control) and nontreated, inoculated with B. cinerea (positive control). Values are the mean of five single-flower replications that were evaluated for $14 \mathrm{~d}$, and asterisks beside the bar indicate significant differences in the longevity of cut flowers within the treatments compared with the positive control $(F=6.82, \mathrm{df}=$ $11, P<0.001)$.

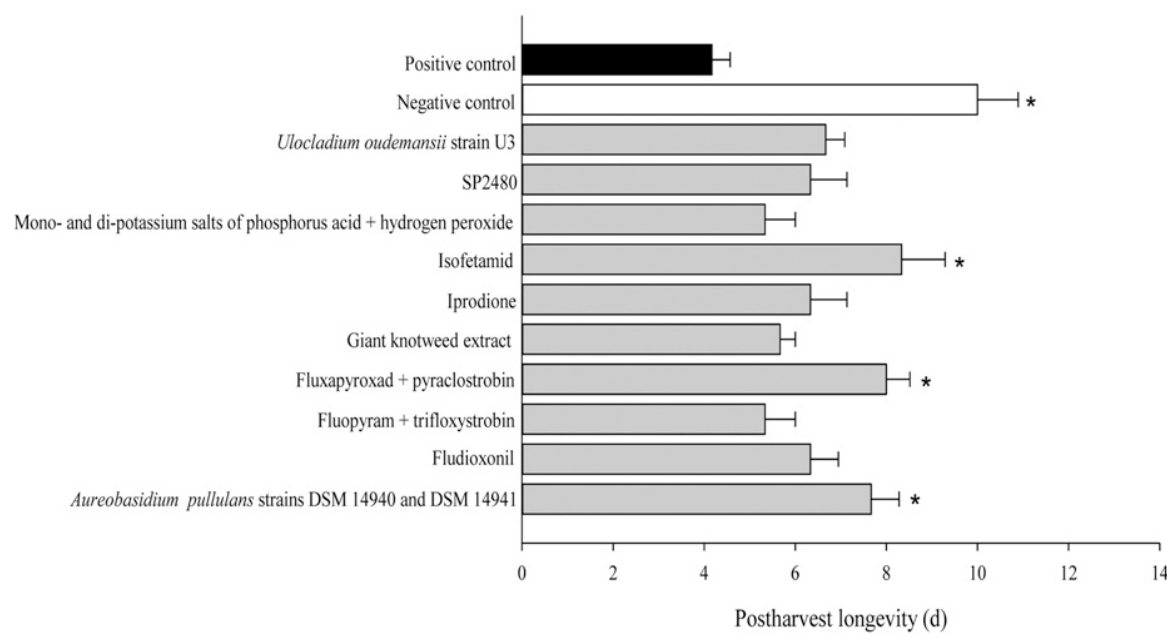

Fig. 2. Postharvest longevity (mean $\pm \mathrm{SE}$ ) of bigleaf hydrangea cut flowers after postharvest dip application of fungicides and biorational products (Table 1 ) and inoculation with Botrytis cinerea (dip Trial I). The bigleaf hydrangea flowers were dipped for $10 \mathrm{~s}$ in treatment solution immediately after harvesting, and then cold stored for $3 \mathrm{~d}$ and displayed in a normal room condition. Longevity is the period from harvest until flowers were rated 3 or more in marketability scale.

Marketability of cut flowers was evaluated using a 1 to 5 ordinal scale $(1=$ dead, 2 = poor quality, $3=$ commercially acceptable, $4=$ good quality, $5=$ healthy). Control treatments included the nontreated, noninoculated (negative control) and nontreated, inoculated with $B$. cinerea (positive control). Values are the mean of six single-flower replications that were evaluated for $12 \mathrm{~d}$, and asterisks beside the bar indicate significant differences in longevity of cut flowers within the treatments compared with the positive control $(F=5.66, \mathrm{df}=11, P<0.001)$. flowers. However, black application residue of $U$. oudemansii strain $\mathrm{U} 3$ was observed in all treated flowers, whereas pink residue of giant knotweed extract was observed in two out of five treated flowers.

EFFICACY OF PREVENTIVE POSTHARVEST DIP APPLICATION OF FUNGICIDES AND BIORATIONAL PRODUCTS. Botrytis blight symptom development was observed in $3 \mathrm{~d}$ after artificial inoculation on bigleaf hydrangea flowers. Negative control and positive control hydrangea flowers had the lowest and highest disease severity (Trial I: $F=10.71, P<$ 0.001; Trial II: $F=42.06, P<0.001$ ) and AUDPC (Trial I: $F=14.79, P<$ 0.001 ; Trial II: $F=151.02, P<$ $0.001)$ in either of the dip application trials, respectively (Table 2 ). The negative control flowers maintained the longest postharvest vase life (Trial I: $10 \mathrm{~d}, F=5.66, P<0.001$; Trial II: $13 \mathrm{~d}, F=65.45, P<0.001$ ) (Figs. 2 and 3 ).

In the first dip trial, isofetamid (33.8\%), fluxapyroxad + pyraclostrobin $(33.8 \%), A$. pullulans strains DSM 14940 and DSM 14941 (42.2\%), and fludioxonil (46.3\%) significantly reduced postharvest botrytis blight disease severity compared with the positive control flowers $(88.0 \%)$ and were statistically equivalent to the negative control (17.2\%) (Table 2). Isofetamid and fluxapyroxad + pyraclostrobin substantially lowered disease progress and were not statistically different from the negative control. A. pullulans strains DSM 14940 and DSM 14941, $U$. oudemansii strain U3, iprodione, fludioxonil, giant knotweed extract, and SP2480 reduced the botrytis blight postharvest progression compared with the positive control flowers, but they were not statistically equivalent to the negative control. Fluopyram + trifloxystrobin and mono and $\mathrm{di}^{-}$ potassium salts of phosphorus acid + hydrogen peroxide were ineffective in reducing disease progress. Isofetamid, fluxapyroxad + pyraclostrobin, A. pullulans strains DSM 14940 and DSM 14941, and fludioxonil significantly reduced botrytis blight disease severity during the entire experiment period, whereas iprodione, SP2480, mono and di-potassium salts of phosphorus acid + hydrogen peroxide, giant knotweed extract, and $U$. oudemansii strain U3 were effective up to 


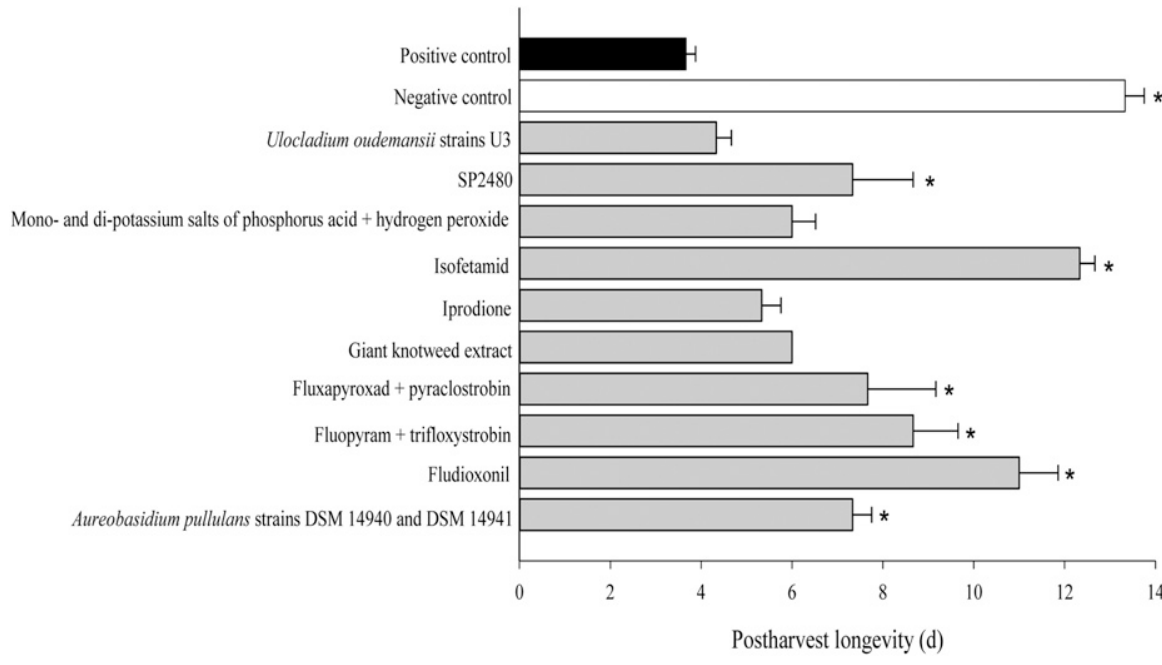

Fig. 3. Postharvest longevity (mean $\pm \mathrm{SE}$ ) of bigleaf hydrangea cut flowers after postharvest dip application of fungicides and biorational products (Table 1 ) and inoculation with Botrytis cinerea (dip Trial II). The bigleaf hydrangea flowers were dipped for $10 \mathrm{~s}$ in treatment solution immediately after harvesting, and then cold stored for $3 \mathrm{~d}$ and displayed in a normal room condition. Longevity is the period from harvest until flowers were rated 3 or more in marketability scale. Marketability of cut flowers was evaluated using a 1 to 5 ordinal scale $(1=$ dead, 2 = poor quality, $3=$ commercially acceptable, $4=$ good quality, $5=$ healthy). Control treatments included the nontreated, noninoculated (negative control) and nontreated, inoculated with $B$. cinerea (positive control). Standard error $=0$ for the mean postharvest longevity of giant knotweed extract. Values are the mean of six single-flower replications that were evaluated $16 \mathrm{~d}$, and asterisks beside the bar indicate significant differences in longevity of cut flowers within the treatments compared with the positive control $(F=65.45$, df $=11, P<0.001)$.

$8 \mathrm{~d}$ of postharvest life in this trial (data not shown). The fungicides isofetamid $(8 \mathrm{~d})$ and fluxapyroxad + pyraclostrobin $(8 \mathrm{~d})$, and the biorational product A. pullulans strains DSM 14940 and DSM 1494l (8 d) significantly maintained longer postharvest vase life of bigleaf hydrangea cut flowers than the positive control (4 d) (Fig. 2).

In the second dip trial, isofetamid (2.2\%), fludioxonil (25.5\%), fluopyram + trifloxystrobin $(33.8 \%)$, and fluxapyroxad + pyraclostrobin $(40.0 \%)$ significantly reduced postharvest botrytis blight symptom development and disease severity compared with the positive control flowers $(88.0 \%)$, with isofetamid, fludioxonil, and fluopyram + trifloxystrobin statistically equivalent to the negative control (Table 2). Isofetamid, fludioxonil, and fluopyram + trifloxystrobin reduced disease progress significantly and were statistically equivalent to the negative control, while fluxapyroxad + pyraclostrobin, SP2480, and A. pullulans strains DSM 14940 and DSM 14941 lowered disease incidence but were not equivalent to the negative control. $U$. oudemansii strain U3, iprodione, mono and di-
However, noticeable residues occurred after applications of $U$. oudemansii strain U3 (black) and giant knotweed extract (pink) in all treated hydrangea flowers.

\section{Discussion}

In this study, efficacy of preharvest whole-plant spray and postharvest dip applications of conventional fungicides and biorational products were screened for efficacy against botrytis blight, caused by $B$. cinerea, on bigleaf hydrangea cut flowers. Inoculated, nontreated flowers (positive controls) consistently showed the highest postharvest botrytis blight disease severity and disease progress. The disease symptoms in positive controls were observed immediately after removal from cold storage $\left(4^{\circ} \mathrm{C}\right)$, and positive control flowers were severely impacted by botrytis blight within $5 \mathrm{~d}$. Similarly, $B$. cinerea infection was observed in freesia (Freesia $\times$ bybrida) flowers when stored in $5^{\circ} \mathrm{C}$; the symptom development was slow but ceaseless (Darras et al., 2006). Botrytis cinerea is an opportunistic pathogen that can even cause infection at low temperatures [i.e., $<5{ }^{\circ} \mathrm{C}$ (Couey and Follstad, 1996)], and it mostly affects stressed and senescent plant tissues (Williamson et al., 2007). The cut flowers are under stressful conditions during postharvest life, which makes them vulnerable to $B$. cinerea infection. Botrytis blight management in bigleaf hydrangea cut flowers is thus important for better postharvest vase life.

Isofetamid (Astun; OHP, Bluffton, SC) and fluxapyroxad + pyraclostrobin (Orkestra Intrinsic), fungicides that interfere with fungal cellular respiration, effectively reduced the postharvest botrytis blight disease severity and disease progress in all trials (whole-plant spray and dip applications). This finding was like other studies where isofetamid significantly reduced botrytis blight disease severity in bigleaf hydrangea, grape (Vitis vinifera), and strawberry (Fragaria xananassa) (Baysal-Gurel et al., 2018; Cavotto et al., 2018; Piqueras et al., 2014). Similarly, fluxapyroxad and pyraclostrobin, when applied alone or in combination, effectively managed botrytis blight and other fungal diseases (Chen et al., 2014; Min et al., 2014; Rebollar-Alviter and 
Ellis, 2005; Shi et al., 2020; Vea and Palmer, 2020). The mixture of two chemical classes may also add flexibility (multiple target sites) in their action against phytopathogens (Pscheidt et al., 2017). Isofetamid and fluxapyroxad belong to the SDHI class of fungicides, and pyraclostrobin belongs to the QoI class of fungicides (FRAC, 2020). The SDHI and QoI fungicides block the electron transport system in fungal mitochondria, which interrupts the cellular energy cycle and, ultimately, results in the death of the fungi (Veloukas and Karaoglanidis, 2012; Zeng et al., $2015)$. Fluxapyroxad + pyraclostrobin is not labeled for dip application, so growers must manage botrytis blight preharvest when using this product. Fluopyram + trifloxystrobin (Broadform) did not effectively reduce postharvest botrytis blight severity and disease progress or maintain vase life of cut flowers in the current study. Disease severity increased after cold storage, reaching a maximum within $7 \mathrm{~d}$ of postharvest vase life. A similar result was reported by Vea and Palmer (2020), that the mixture of fluopyram and trifloxystrobin did not provide effective control of botrytis blight in geranium. However, fluopyram + trifloxystrobin effectively managed $B$. cinerea infection only in dip Trial II. The increased efficacy of fluopyram + trifloxystrobin (as well as isofetamid in dip Trial II) might be due to lower relative humidity $(62 \%)$ in the flower display room, which might have slowed the growth of $B$. cinerea compared with conditions during the dip application Trial I $(\mathrm{RH}=68 \%)$. Eden et al. (1996) observed a low level of $B$. cinerea infection on tomato (Solanum lycopersicum) flowers at $56 \% \mathrm{RH}$. However, a significant positive correlation between $\mathrm{RH}$ and $B$. cinerea infection was observed (i.e., flower infection increased under higher $\mathrm{RH})$.

Fludioxonil (Medallion; Syngenta, Greensboro, NC), a phenylpyrrole class fungicide, substantially managed the postharvest botrytis blight of bigleaf hydrangea cut flowers during the entire experiment period. The preventive postharvest dip application of fludioxonil was effective in reducing botrytis blight disease severity and extending postharvest vase life of cut flowers. Fludioxonil interferes with the osmoregulatory pathway of fungi (Hahn, 2014), inhibiting the germination of spores and growth and development of mycelium (Kim et al., 2016). In tulip (Tulipa sp.) flowers, application of fludioxonil significantly reduced the number of blighted flowers and disease severity (Chastagner and DeBauw, 2017). However, preharvest wholeplant spray application of fludioxonil did not effectively reduce botrytis blight disease severity and disease progress in this study. This result may have been due to the conducive environmental conditions in the greenhouse and a higher inoculum level (i.e., $10^{6}$ conidia $/ \mathrm{mL}$ ) that have facilitated $B$. cinerea infection, so that any treatment benefit was overcome. Further, fludioxonil is a nonsystemic fungicide and is not absorbed by the plant, so its efficacy is based on contact. Fludioxonil may break down too quickly in the environment after application, which would limit its efficacy; and sometimes the spraying method only provides fungicide coverage on exposed surface, leaving the unexposed side of sepals without treatment. Any pathogen like $B$. cinerea that can initially infect plants and reside there until suitable conditions occur for greater colonization can avoid subsequent surface treatments. Thus, the greater efficacy seen with the dipping method in our study may have been due to better surface coverage on flowers compared with the whole-plant spray method.

Iprodione (Chipco 26019, Bayer), a fungicide in the dicarboximide chemical group, was not effective in controlling postharvest botrytis blight management in bigleaf hydrangea cut flowers. Similar inconsistent results for iprodione were observed in strawberry and grapevine in controlling postharvest $B$. cinerea infection (Blacharski et al., 2001; Kim et al., 2016). In contrast, postharvest spray of iprodione with fan drying and dip application in rose flower and strawberry transplants showed good efficacy in managing botrytis blight severity (Goss and Mazarura, 2013; Oliveira et al., 2018). The poor performance of iprodione in this study could have been due to the use of only a single application, or the applied concentration was not high enough, or perhaps the isolate of $B$. cinerea used is insensitive to iprodione.
Increases in antifungal activity of iprodione inhibiting spore germination and mycelium growth of $B$. cinerea have been observed with increases in concentration (Kim et al., 2016).

Saprophytic ascomycete $A$. pullulans strains have been found effective in reducing postharvest botrytis blight (Castoria et al., 2001; Weiss et al., 2014). The antagonist activity of $A$. pullulans against pathogens is due to competition for nutrients and niches as well as production of some enzymes such as proteases and chitinases (Freimoser et al., 2019). In this study, A. pullulans strains DSM 14940 and DSM 14941 (Botector; Westbridge Agriculture Products, Vista, CA) showed slightly ineffective (preharvest whole-plant spray application) to effective (postharvest dip application) results in controlling the postharvest botrytis blight disease progression. The moderate performance of $A$. pullulans strains DSM 14940 and DSM 14941 in preharvest whole-plant spray application might have been due to less conducive greenhouse conditions for colonization of flower tissues. Bigleaf hydrangea plants were sprayed with $A$. pullulans DSM 14940 and DSM 14941 three days before the harvest and remained in the greenhouse under a condition of lower humidity and warmer temperature than the condition following dip applications, where flowers were taken to cold storage after treatment. According to Rotolo et al. (2018), high-disease pressure spraying with $A$. pullulans strains DSM 14940 and DSM 14941 alone (up to 11 sprays) did not give satisfactory results in managing $B$. cinerea infection in grapevine; however, application of these strains was effective when integrated with SDHI fungicides. Overall, $A$. pullulans strains DSM 14940 and DSM 14941 show good potential for use in combination or rotation with reduced-risk fungicides.

Another biocontrol agent, $U$. oudemansii strain U3 (BWl65N; BioWorks, Victor, NY), showed inconsistent performance in reducing the postharvest botrytis blight disease severity and disease progress as well as in maintaining postharvest vase life. This finding contradicts previous work (Calvo-Garrido et al., 2014; Thomidis et al., 2015), where applications of $U$. oudemansii strain U3 
substantially reduced botrytis blight incidence and disease severity in grape and strawberry. Time for establishment of biological control agents on host tissue before the pathogen is crucial for proper disease suppression. According to Kessel et al. (2002), sporulation of $B$. cinerea was not significantly reduced when $U$. atrum was applied $12 \mathrm{~h}$ or less before $B$. cinerea inoculation; however, when $U$. atrum was given 48 $\mathrm{h}$ head-start time, it completely suppressed the sporulation of $B$. cinerea in cyclamen leaf tissue. In this study, plants or flowers were inoculated with $B$. cinerea conidial suspension about 2 to $3 \mathrm{~h}$ after treatment with $U$. oudemansii strain $\mathrm{U} 3$, which might not have been enough time for $U$. oudemansii strain U3 to become well established on host tissue. Therefore, further inquiries are needed to elucidate the length of time required for U. oudemansii strain U3 to be established before $B$. cinerea challenge for optimal suppression. In addition, more study is needed to determine the concentration and number of additional applications required for $U$. oudemansii strain U3 to produce satisfactory postharvest botrytis blight reduction.

Except for $A$. pullulans strains DSM 14940 and DSM 14941, the biorational products tested under these conditions showed ineffective results. The biorational product $U$. oudemansii strain U3, mono and dipotassium salts of phosphorus acids + hydrogen peroxide (OxiPhos; BioSafe Systems, Harford, CT), giant knotweed extract (Regalia; Marrone Bio Innovations, Davis, CA), and SP2480 (experimental extract; SePRO, Carmel, IN) were not effective in reducing botrytis blight severity and maintaining the postharvest vase life of cut flowers. It is not uncommon for biorationals to perform differently in different test systems or across experiments in the same test system. For example, variable efficacy results were observed with giant knotweed extract when screening for botrytis blight disease efficacy in tulip and asiatic hybrid lilies [Lilium $\times$ asiatica (Chastagner and DeBauw, 2014, 2017)]; however, it was found to be effective in protecting pruning wounds and leaves of tomato against botrytis blight (Bardin et al., 2008). Further studies are warranted looking at rate ranges and application of biorational products multiple times during production in addition to preharvest or postharvest treatments, endeavors outside the scope of these screening experiments.

The postharvest vase life of cut flowers is one of the most important quality determinants in the cut flower market because flowers often are subjected to lengthy handling, storage, and transportation processes. The increased postharvest vase life shown here from application of conventional fungicides and biorational products likely is due to reduction in postharvest botrytis blight disease severity, which facilitates better physiological functioning of bigleaf hydrangea cut flowers.

In ornamental production, curative fungicide applications for botrytis blight are not considered an appropriate strategy because any slight incidence of disease can ruin the ornamental characteristics of flowers. Thus, preventive application of fungicides/biorational products should be a major strategy for botrytis blight management to maintain the quality of the product and remain competitive in the market. The efficacy of fungicides and biorational products depends upon several factors related to the plant and application of the product, as well as the environmental conditions. This study used a single, diploid cultivar of bigleaf hydrangea, whereas triploid cultivars of hydrangea have thicker sepals and altered stomatal structure (Alexander, 2017). Disease severity, disease progress, and efficacy of fungicides and biorational products should be evaluated in more cultivars to gain a more complete picture of postharvest botrytis blight management in bigleaf hydrangea flowers. Application variables that may affect efficacy include concentration, timing and frequency, methods of application, and stage of flower development. This study tested the single application of fungicides and biorational products as preharvest and postharvest treatments. Only isofetamid and fluxapyroxad + pyraclostrobin consistently reduced the postharvest botrytis blight disease severity, and these two products also maintained the longer vase life of bigleaf hydrangea cut flowers in both preventive application methods. Fludioxonil and $A$. pullulans strains DSM 14940 and DSM 14941 significantly lowered the disease severity and improved postharvest vase life when applied as a postharvest dip treatment. All other treatments showed variable efficacy (slightly effective to ineffective) for botrytis blight management. Results of this study will provide growers with improved strategies for postharvest botrytis blight management to protect the quality and value of cut flowers.

\section{Literature cited}

Adkins, J.A., M.A. Dirr, and O.M. Lindstrom. 2003. Cold hardiness estimates for ten Hydrangea taxa. Acta Hort. 618:163168.

Alexander, L. 2017. Production of triploid Hydrangea macrophylla via unreduced gamete breeding. HortScience 52:221-224.

Arafa, A.M.S., A.A. Nower, S.S. Helme, and H.A. Abd-Elaty. 2017. Large scales of Hydrangea macrophylla using tissue culture technique. Intl. J. Curr. Microbiol. Appl. Sci. 6:776-778.

Bardin, M., J. Fargues, and P.C. Nicot. 2008. Compatibility between biopesticides used to control grey mould, powdery mildew and whitefly on tomato. Biol. Control 46:476-483.

Baysal-Gurel, F., N. Kabir, and A. Blalock. 2016. Foliar diseases of hydrangeas. Tennessee State Univ., Coll. Agric. Hum. Nat. Sci. ANR-PATH-5-2016:1-7.

Baysal-Gurel, F. and T. Simmons. 2017. Evaluation of fungicides for control of botrytis blight on hydrangea, 2016. Plant Dis. Manag. Rep. OT022. doi: 10.1094/ PDMRIl.

Baysal-Gurel, F., T. Simmons, M. Turner, and A. Fancher. 2018. Evaluation of fungicides for control of botrytis blight on detached hydrangea leaves, 2017. Plant Dis. Manag. Rep. OT010. doi: 10.1094/ PDMR12.

Bika, R., F. Baysal-Gurel, and C. Jennings. 2020. Botrytis cinerea management in ornamental production: A continuous battle. Can. J. Plant Pathol., doi: 10.1080/07060661.2020.1807409.

Blacharski, R.W., J.A. Bartz, C.L. Xiao, and D.E. Legard. 2001. Control of postharvest botrytis fruit rot with preharvest fungicide applications in annual strawberry. Plant Dis. 85:597-602.

Bock, C.H., T.R. Gottwald, P.E. Parker, A.Z. Cook, F. Ferrandino, S. Parnell, and F. van den Bosch. 2009. The HorsfallBarratt scale and severity estimates of citrus canker. Eur. J. Plant Pathol. 125:2338 . 
Calvo-Garrido, C., I. Viñas, P.A. Elmer, J. Usall, and N. Teixidó. 2014. Suppression of Botrytis cinerea on necrotic grapevine tissues by early-season applications of natural products and biological control agents. Pest Manag. Sci. 70:595-602.

Castoria, R., F. De Curtis, G. Lima, L. Caputo, S. Pacifico, and V. De Cicco. 2001. Aureobasidium pullulans (LS-30) an antagonist of postharvest pathogens of fruits: Study on its modes of action. Postharvest Biol. Technol. 22:7-17.

Cavotto, A., N. Frasso, E. Archer, and L. Logothesis. 2018. Isofetamid: Nuovo fungicida per il controllo della Botrite Della Vite e della fragola e della moniliosi delle drupacee. Atti Giornate Fitopatollogiche 2:11-20.

Chastagner, G.A. and A. DeBauw. 2014. Effectiveness of reduced-risk and biocontrol products in controlling fire on lilies. Acta Hort. 1027:231-240.

Chastagner, G.A. and A. DeBauw. 2017. Integration of bio-fungicides in botrytis disease management programs on fieldgrown ornamental geophytes. Acta Hort. 1171:331-340.

Chen, Y., J. Yao, X. Yang, A.F. Zhang, and T.C. Gao. 2014. Sensitivity of Rhizoctonia solani causing rice sheath blight to fluxapyroxad in China. Eur. J. Plant Pathol. 140:419-428.

Couey, H. and M. Follstad. 1996. Heat pasteurization for control of postharvest decay in fresh strawberries. Phytopathology 56:1345-1347.

Darras, A.I., L.A. Terry, and D.C. Joyce. 2005. Methyl jasmonate vapour treatment suppresses specking caused by Botrytis cinerea on cut Freesia bybrida L. flowers. Postharvest Biol. Technol. 38:175-182.

Darras, A.I., D.C. Joyce, L.A. Terry, and I. Vloutoglou. 2006. Postharvest infection of Freesia hybrida flowers by Botrytis cinerea. Australas. Plant Pathol. 35:55-63.

Debieu, D., J. Bach, M. Hugon, C. Malosse, and P. Leroux. 2001. The hydroxyanilide fenhexamid, a new sterol biosynthesis inhibitor fungicide efficient against the plant pathogenic fungus Botryotinia fuckeliana (Botrytis cinerea). Pest Manag. Sci. 57:1060-1067.

Eden, M., R. Hill, R. Beresford, and A. Stewart. 1996. The influence of inoculum concentration, relative humidity, and temperature on infection of greenhouse tomatoes by Botrytis cinerea. Plant Pathol. 45:795-806.

Elad, Y. 1988. Latent infection of Botrytis cinerea in rose flowers and combined chemical and physiological control of the disease. Crop Prot. 7:361-366.
Fernández-Ortuño, D., A. Grabke, X. Li, and G. Schnabel. 2015. Independent emergence of resistance to seven chemical classes of fungicides in Botrytis cinerea. Phytopathology 105:424-432.

Fravel, D.R. 2005. Commercialization and implementation of biocontrol. Annu. Rev. Phytopathol. 43:337-359.

Freimoser, F.M., M.P. Rueda-Mejia, B. Tilocca, and Q. Migheli. 2019. Biocontrol yeasts: Mechanisms and applications. World J. Microbiol. Biotechnol. 35:1-19.

Fulcher, A.F., J.S. Owen, and A. Lebude. 2016. Hydrangea production: Speciesspecific production guide. Univ. Tennessee, UT Extension. PB 1840-B:1-12.

FRAC (Fungicide resistance action committee). 2020. FRAC code list 2020: Fungicides sorted by mode of action (including FRAC code numbering). 23 Apr. 2020. <https://www.frac.info/docs/ default-source/publications /frac-codelist/frac-code-list-2020 final5d632b2c5 12362 eb 9 a 1 eff 00004 acf 5 d.pdf? sfvrsn=f940499a_2>.

Goss, M. and U. Mazarura. 2013. Efficacy of postharvest fungicide sprays and fandrying for the control of gray mould (Botrytis cinerea) in roses (Rosacea bybridus var. 'Annabella'). Agr. Technol. Thail. 9:413-420.

Gullino, M.L. and A. Garibaldi. 2007. Critical aspects in management of fungal diseases of ornamental plants and directions in research. Phytopathol. Mediterr. 46:135-149.

Hahn, M. 2014. The rising threat of fungicide resistance in plant pathogenic fungi: Botrytis as a case study. J. Chem. Biol. 7:133-141.

Hu, J., S.Q. Dinh, and D.C. Joyce. 2009. S-carvone effects on Botrytis cinerea and harvested waxflower (Chamelaucium). N. Z. J. Crop Hort. Sci. 37:79-83.

IR-4 Project. 2019. Botrytis efficacy: Cut flower crops with postharvest/shelf life evaluation protocol: 19-002. 2019. 7 May 2020. <https://www.ir4project. org/ehc/ehc-registration-\%20supportresearch/env-hort-researcher-resources/ \#Protocols>.

Kazaz, S., T. Kılıç, E. Doğan, and Ş. Sekmen. 2020. Vase life extension of cut hydrangea (Hydrangea macrophylla) flowers. J. Hort. Sci. Biotechnol. 95:325330 .

Kessel, G.J.T., B.H. De Haas, W. Van Der Werf, and J. Köhl. 2002. Competitive substrate colonization by Botrytis cinerea and Ulocladium atrum in relation to biological control of $B$. cinerea in cyclamen. Mycol. Res. 106:716-728.
Kim, J.O., J.H. Shin, A. Gumilang, K. Chung, K.Y. Choi, and K.S. Kim. 2016. Effectiveness of different classes of fungicides on Botrytis cinerea causing gray mold on fruit and vegetables. Plant Pathol. J. 32:570-574.

Leroux, P. 1996. Recent developments in the mode of action of fungicides. Pestic. Sci. 47:191-197.

McClintock, E. 1957. A monograph of the genus Hydrangea. Proc. Calif. Acad. Sci. 29:147-256.

Milling, R.J. and C.J. Richardson. 1995. Mode of action of the anilino-pyrimidine fungicide pyrimethanil. 2. Effects on enzyme secretion in Botrytis cinerea. Pestic. Sci. 45:43-48.

Min, K.H., J.P. Ryu, J.M. Kim, S.H. Kim, S.H. Yim, J.J. Choi, B.H. Cho, and K.Y. Yang. 2014. Control efficacy of the mixture of fluxapyroxad plus pyraclostrobin against pear scab caused by Venturia nashicola. Korean J. Pestic. Sci. 18:434-438.

Morandi, M.A.B., J.C. Sutton, and L.A. Maffia. 2000. Effect of host and microbial factor on development of Clonostachys rosea and control of Botrytis cinerea in rose. Eur. J. Plant Pathol. 106:439-448.

Muñoz, M., J.E. Faust, and G. Schnabel. 2019. Characterization of Botrytis cinerea from commercial cut flower roses. Plant Dis. 103:1577-1583.

Oliveira, M.S., L.G. Cordova, M.V. Marin, and N.A. Peres. 2018. Fungicide dip treatments for management of Botrytis cinerea infection on strawberry transplants. Plant Heal. Prog. 19:279-283.

Pagter, M. and M. Williams. 2011. Frost dehardening and rehardening of $\mathrm{Hy}$ drangea macrophylla stems and buds. HortScience 46:1121-1126.

Piqueras, C.M., B.A. Latorre, and R. Torres. 2014. Effectiveness of isofetamid, a new succinate dehydrogenase inhibitor fungicide, in the control of grapevine gray mold. Cienc. Investig. Agrar. 41:365-374.

Prusky, D. 1996. Pathogen quiescence in postharvest disease. Annu. Rev. Phytopathol. 34:413-434.

Pscheidt, J.W., S. Heckert, and S.A. Cluskey. 2017. Evaluation of quinone outside and succinate dehydrogenase inhibitors for effectiveness against eastern filbert blight of hazelnut. Plant Dis. 101:1868-1873.

Rebollar-Alviter, A. and M.A. Ellis. 2005. Efficacy of azoxystrobin, pyraclostrobin, potassium phosphite and mefenoxam for control of strawberry leather rot caused by Phytophthora cactorum. Plant Heal. Prog. 6:17. 
Reddy, P.P. 2016. Sustainable crop protection under protected cultivation. Springer, Singapore.

Redmond, J.C. 1987. Biological control of Botrytis cinerea on roses with epiphytic microorganisms. Plant Dis. 71:799-802.

Rodríguez, A., A. Acosta, and C. Rodríguez. 2014. Fungicide resistance of Botrytis cinerea in tomato greenhouses in the Canary Islands and effectiveness of non-chemical treatments against gray mold. World J. Microbiol. Biotechnol. 30:2397-2406.

Rosslenbroich, H.J. and D. Stuebler. 2000. Botrytis cinerea-History of chemical control and novel fungicides for its management. Crop Prot. 19:557-561.

Rotolo, C., R.M. De Miccolis Angelini, C. Dongiovanni, S. Pollastro, G. Fumarola, M. Di Carolo, D. Perrelli, P. Natale, and F. Faretra. 2018. Use of biocontrol agents and botanicals in integrated management of Botrytis cinerea in table grape vineyards. Pest Manag. Sci. 74:715-725.

Rupp, S., R.W.S. Weber, D. Rieger, P. Detzel, and M. Hahn. 2017. Spread of Botrytis cinerea strains with multiple fungicide resistance in German horticulture. Front. Microbiol. 7:1-12.

Salinas, J. and K. Verhoeff. 1995. Microscopical studies of the infection of gerbara flowers by Botrytis cinerea. Eur. J. Plant Pathol. 101:377-386.

Seglie, L., D. Spadaro, M. Devecchi, F. Larcher, and M.L. Gullino. 2009. Use of 1-methylcyclopropene for the control of Botrytis cinerea on cut flowers. Phytopathol. Mediterr. 48:253-261.

Shi, N., H. Ruan, L. Gan, Y. Dai, X. Yang, Y. Du, and F. Chen. 2020. Evaluating the sensitivities and efficacies of fungicides with different modes of action against Phomopsis asparagi. Plant Dis. 104:448454.

Sierotzki, H. and G. Scalliet. 2013. A review of current knowledge of resistance aspects for the next-generation succinate dehydrogenase inhibitor fungicides. Phytopathology 103:880-887.

Sun, H.Y., H.C. Wang, Y. Chen, H.X. Li, C.J. Chen, and M.G. Zhou. 2010. Multiple resistance of Botrytis cinerea from vegetable crops to carbendazim, diethofencarb, procymidone, and pyrimethanil in China. Plant Dis. 94:551-556.

Sutton, J.C., D. Li, G. Peng, H. Yu, P. Zhang, and R.M. Valdebenito-sanhueza. 1997. Gliocladium roseum a versatile adversary of Botrytis cinerea in crops. Plant Dis. 81:316-328.

Tatagiba, S., L.A. Maffia, R.W. Barreto, A.C. Alfenas, and J.C. Sutton. 1998. Biological control of Botrytis cinerea in residues and flowers of rose (Rosa bybrida). Phytoparasitica 26:8-19.

Thomidis, T., S. Pantazis, E. Navrozidis, and N. Karagiannidis. 2015. Biological control of fruit rots on strawberry and grape by botry-zen. N. Z. J. Crop Hort. Sci. 43:68-72.

Tomas, A., A.H. Wearing, and D.C. Joyce. 1995. Botrytis cinerea: A causal agent of premature flower drop in packaged geraldton waxflower. Australas. Plant Pathol. 24:26-28.

U.S. Department of Agriculture. 2014. 2014 Census of horticulture specialties. 10 May 2020. <http://www.agcensus. usda.gov/Publications/2012>.

Vea, E. and C. Palmer. 2020. Botrytis efficacy summary-2020, The IR-4 Project. 14 May 2020. <https://www.ir4project. org/ehc/researchsummary/efficacy/ botrytis-efficacy-summary-2020>.

Veloukas, T. and G.S. Karaoglanidis. 2012. Biological activity of the succinate dehydrogenase inhibitor fluopyram against Botrytis cinerea and fungal baseline sensitivity. Pest Manag. Sci. 68:858-864.

Weiss, A., S. Weißhaupt, P. Krawiec, and S. Kunz. 2014. Use of Aureobasidium pullulans for resistance management in chemical control of Botrytis cinerea in berries. Acta Hort. 1017:237-242.

Welch, B. 1947. The generalization of student's problem when several different population variances are involved. Biometrika 34:23-35.

Williamson, B., B. Tudzynski, P. Tudzynski, and J.A.L. Van Kan. 2007. Botrytis cinerea: The cause of grey mould disease. Mol. Plant Pathol. 8:561-580.

Yoshida, K., Y. Toyama-Kato, K. Kameda, and T. Kondo. 2003. Sepal color variation of Hydrangea macrophylla and vacuolar $\mathrm{pH}$ measured with a proton-selective microelectrode. Plant Cell Physiol. 44:262268.

Zaldúa, S. and E. Sanfuentes. 2010. Control of Botrytis cinerea in eucalyptus globulus mini-cuttings using Clonostachys and Trichoderma strains. Chil. J. Agr. Res. 70:576-582.

Zeng, F., E. Arnao, G. Zhang, G. Olaya, J. Wullschleger, H. Sierotzki, R. Ming, B.H. Bluhm, J.P. Bond, A.M. Fakhoury, and C.A. Bradley. 2015. Characterization of quinone outside inhibitor fungicide resistance in Cercospora sojina and development of diagnostic tools for its identification. Plant Dis. 99:544-550.

Zhao, P., A. Ren, P. Dong, Y. Sheng, X. Chang, and X. Zhang. 2018. The antimicrobial peptaibol trichokonin IV promotes plant growth and induces systemic resistance against Botrytis cinerea infection in moth orchid. J. Phytopathol. 166:346-354

Zheng, L., J.M. Diamond, and D.L. Denton. 2013. Evaluation of whole effluent toxicity data characteristics and use of Welch's $t$-test in the test of significant toxicity analysis. Environ. Toxicol. Chem. $32: 468-474$ 